\title{
Railways and Urban Transformation: The Case of Konya
}

\author{
By Emrah Yilmaz
}

This paper studies the central Anatolian city named Konya and its transformation into a pioneering city of the Ottoman Empire by the establishment of the railways. During the Era of Sultan Abdülhamit II, Konya was a traditional Anatolian city. Towards the end of the 19th century, by the arrival of the Anatolia Railway Line (July 1896), its destiny changed. Comparisons of the developments within the city during the period of Abdülhamit II and after the establishment of the railways showed that the first transformation began with the city's structure. The traditional structure quickly began to change by the construction of the Eskisehir-Konya railway line. New businesses and localities, which haven't been in the city before, began to be established. The existence of these new localities and the construction of the railway opened doors not only to nearby cities but also to other nations and countries within the borders of the Empire, and also to the international world. Thus, a population movement, especially an internal migration, began eventually as Konya was surrounded with modern structures. In addition, by the arrival of the Railways to Konya, cereal transport, which was minimal before, showed an increase, and Konya began to meet the cereal demand of the capital city of Istanbul partially. The Konya Plain Irrigation Project started and was conducted by the Anatolia Railways Company in order to increase the variety of products, and the arable lands made Konya and its vicinity one of the pioneer places of the Ottoman Empire's development. This paper studies how the structure of a city changed by the establishment of railways.

\section{Introduction}

Railways have become one of the most significant symbols of the Industrial Revolution after factories. A revolution in transportation was experienced after railways, and the meanings of concepts such as time, place and distance changed in the human mind. Railways have been both the tool of imperialism in the world, and have changed and converted the human and urban life and the agricultural structure faster than ever before. Also one of the significant examples of the change that railways brought to the human and urban life and to the agricultural development was experienced in Konya. An extension of the railways to Konya is a significant breaking point in the city history, and it has the quality to explain the structural change experienced in the last years of the $19^{\text {th }}$ century. ${ }^{1}$ Referring to the general characteristic

\footnotetext{
${ }^{*}$ Research Assistant, Department of History, Faculty of Letters, Anadolu University, Turkey.

1. A. Efe, "Rayların Altında Kalan Mâkus Tarih: Değişen Eskişehir" ["The unfortunate history Stucked Under the Railraod Tracks: Changing Eskişehir"] in Railways in the Republic Period Symposium, ed. Mukaddes Arslan (Ankara: Atatürk Research Center, 2010), 117 - 118 ; E. Yılmaz, "II. Abdülhamit Döneminde Konya ve Kentin Yapısal Değişimi" ["The Structural
} 
structure of Konya in the period of Abdülhamit II, which is important in terms of our subject, and the development of the Konya railways is going to be beneficial for the subject to be understood in a multidimensional manner.

\section{Socio-Economic Structure of Konya in the Last Quarter of the $19^{\text {th }}$ Century}

As we will mention Konya in the last quarter of the $19^{\text {th }}$ century, we are going to dwell on agriculture and the agricultural developments of Konya primarily. The Konya region is located in the continental climate zone due to its geographical position. The continental climate has affected the variety of products as well as it reduced the soil fertility. Therefore, we can say that grain farming has become mandatory in Konya and in its vicinity. ${ }^{2}$ In the yearbook of the Konya province dated 1876, the year in which Abdülhamit acceded to the throne, the crops harvested in Konya, which are products such as wheat, barley, rye, oats, and opium poppy, show the density of grain farming, and it demonstrates our argument. ${ }^{3}$ Again in this period, drought in the Konya Plain shows up as a significant problem. The drought caused by climate conditions in Konya has reached to significant levels in the years 1887/8 A.D. This drought was named as the Hijri 1303 (1887) famine, and it was passed down from one generation to another. These droughts had taken an important place on memories, and its affects had continued for years. ${ }^{4}$ It can be said that significant measures were taken by the Ottoman Empire in the matter of increasing the agricultural production in Konya. One of these attempts is the establishment of the Konya Numune Field in 1889, and these fields were established in order to make an agricultural progress that can be acknowledged as a significant symbol of agricultural modernization. ${ }^{5}$ The agricultural production in Konya was intended more for the household consumption, and this structure has started to break down after the arrival of railways to Konya. In the Ottoman Empire's largest province Konya, it is seen that no significant production was beside the point in terms of industrial products in the last quarter of the $19^{\text {th }}$ century, and the conventional industrial structure was dominant. Considering the industrial products of Konya in this period, these products stand out as the bulk products which were more likely to be based on agriculture and animal husbandry. In the province yearbook dated 1881 (Hijri

Changes in Konya and the City During The Period of Abdulhamit II"] (master's thesis, Anadolu University Institute of Social Sciences, 2015).

2. O. Kizılkaya and T. Akay, II. Abdülhamit'in Tarımsal Kalkınma Hamlesi (Konya Ovası Sulama Projesi) [Agricultural Development Act of Abdulhamit II, Konya Plain Irrigation Project] (Ankara: Sonçağ Publications, 2014), 9 -10.

3. Konya Province Yearbook, 1294 Islamic Calendar, No. 10, 110.

4. M. Yılmaz, "Konya ve Havalisinde 1303 (1887) Kıtlı̆̆ı ve Alınan Bazı Tedbirler" ["Famine in Konya and its Vicinity in 1303 Hijri (1887) and the Some Measures Taken to Prevent It"] in Yeni Ipek Yolu Mazagine Konya I Book Special Edition, ed. Yusuf Küçükdağ, 135 - 146. 1998.

5. Konya Province Yearbook, 1317 Islamic Calendar, No. 28, 73. 
1298), it is stated that shoe-making, leather and leather products consist of felt, linen and gingham woven with yarn, and at the same time linseed, poppy and sesame oil were also extracted. ${ }^{6}$ It is seen that there had been no significant change in the industrial products of Konya in the next periods. For this reason, the lack of marketplaces, such as bazaars, to sell the manufactured products as well as technical issues like inadequate transportation and technological infrastructure in the region where Konya is located have played a significant role. This one-type production style in industrial products has continued for years. A change in this of one-type industrial production has been possible by the arrival of railways to Konya in the late $19^{\text {th }}$ century, and when Konya managed to get into the international market. ${ }^{7}$ It is stated that the carpet business made a significant progress towards the end of the $19^{\text {th }}$ century in Konya. In Konya, which is one of the significant centers of carpet business in Central Anatolia, we witness the existence of local female carpet manufacturers as well as the spreading of house and workshop style carpet production in this period. Among the reasons of the development of the carpet business in Konya and in its vicinity, the madder called Cehri and the wool/the fleece wool obtained from sheep and goat farming, which is a significant source of income in Konya, have made a huge contribution. The madder interpreted as Cehri and the fleece wool have also played a significant role in the foreign trade of Konya, and they were exported to imperial factories located both in Istanbul and abroad for a long time. ${ }^{8}$ The carpets woven in Konya and its appendages had specific features, and the carpets which vary in features such as color, pattern and quality, were distinctive. Generally vegetal dyes (madder) were used in Konya carpets. Hence this prevented the colors to fade as well as it increased the durability of the carpets. Carpets woven in Konya and its vicinity are known for being famous with their durability and unfading colors. ${ }^{9}$

Explaining the general population structure of Konya in the examined period, and the characteristic features of the population is important in terms of defining the change Konya experienced in the last quarter of the 19th Century. It is also understood that the central district of Konya had a total population of 38757 including its three communes in 1877 (1294 Hijri). ${ }^{10}$ Later in the province yearbook of Konya which was published in $1883 / 4$, we see that the population of the Konya central district had decreased, and the district

6. Konya Province Yearbook, 1298 Islamic Calendar, no. 14, 59-60.

7. E. Y1lmaz, 2015, $45-46$.

8. BOA. BEO (PMOA. HPDR), [Turkish Prime Ministry Ottoman Archives, High Porte Document Room]. 16. B. 1325. 3131/ 234768.

9. T. Büyüksarıkulak, "II. Abdülhamit Dönemi Salnamelerine Göre Konya Vilayeti Merkez Sancağının İktisadi Durumu" ["The Financial Conditions of Konya Province Centre District According to the Yearbooks of Abdulhamit II. Era"] (master's thesis, Selçuk University, 1988), 46; M. Önder, Mevlana Şehri Konya [City of the Mevlana, Konya] (Ankara: Konya Turizm Derneği Publications, 1971), 421; A. Atalay, "Meşrutiyet'ten Cumhuriyet'e Konya'da Şirketleşme ve Milli Bankacılık Faaliyetleri" ["Incorporation and National Banking Activities from The Constitutional Period to The Republic Period"] (PhD diss., Selcuk University, 2010), 19.

10. Konya Province Yearbook, 1294 Islamic Calendar, no. 10, 152. 
consisted of 17,649 people. Towards the end of the $19^{\text {th }}$ century, the population of Konya started to increase, and since there had been many factors to the population increase, it does not seem possible to explain the increase with an absolute factor. The population of Konya was given as 44,799 in the province yearbook dated 1892/3. Visiting Konya in the 1890s, Vital Cuinet also mentions numbers which are close to the information in the province yearbook. Cuinet had noted the population of Konya as 44,000. Therefore, we can say that the information given in the yearbook and the numbers given by Cuinet match up with each other. ${ }^{11}$

\section{Konya Railways and the Arrival of Railway Line to Konya}

Railways symbolize one of the most significant symbols of the industrial revolution after factories. The Ottoman Empire had tried to implement the railway project in a much shorter time than several improvements, and the projects of railway construction had been on the agenda in the empire on such an early date as the $1830 \mathrm{~s}^{12}$ Since the empire had understood the importance of railways, it started to construct railways by giving privileges to foreign states and companies in the second half of the $19^{\text {th }}$ century. Constructed by the English in Anatolia, and completed in 1866, the Izmir-Aydin Railways constitute the first example of this. ${ }^{13}$ On the other hand, the Anatolian Railway Line had been developed as a result of the empire's intention of extending its railway lines towards the central plain of Anatolia. Germany had completed its political union even if it's late, and attempted to find new life space as a result of this. Being aware of a Germany that is stuck in Europe would not have a word in the world politics, German officials started to spread to the Balkans and Anatolia in an economic manner by following a new foreign policy -Welt Politik-. Deutsche Bank had played a significant role in Germany's expansion in an economic manner. In order to carry out the construction process of the Anatolian Railways in the Ottoman Empire by Deutsche Bank capital, a jointstock company called La Societe du Chemin de fer Ottoman d'Anatolia Anatolian Railway Company was founded on March $23^{\text {rd }} 1889 .{ }^{14}$ Rapidly

11. Konya Province Yearbook, 1310 Islamic Calendar, no. 25, 248; V. Cuinet, La Turquie d'Asie; géographie administrative, statistique descriptive et raisonnée de $l$ asie mineure [Asiatic Turkey; administrative geography, descriptive and reasoned statistics of Asia Minor] (Paris: E. Leroux, 1892), 818 - 819.

12. D. Quataert, "19. Yüzyılda Osmanlı İmparatorluğu'nda Demiryolları" ["Railways in the 19th century in Ottoman Empire"]. Tanzimat'tan Cumhuriyet'e Türkiye Ansiklopedisi. [From Tanzimat to Republican Era Turkey Encyclopedia] Vol.6, Istanbul: İletişim Publications, 1985, 1630.

13. C. Issawi, The Economic History of Turkey 1800 - 1914 (Chicago: The University of Chicago Press, 1980), 183; A. D. Velay, Türkiye Maliye Tarihi [Financial History of Turkey] (Ministry of Finance, Board of Review Publication, 1978), 399.

14. I. Ortayl, Osmanlı Imparatorluğu'nda Alman Nüfuzu [German Influence in The Ottoman Empire] (Istanbul: Alkım Publications, 2006), 120; M. Özyüksel, Osmanlı - Alman İlişkilerinin Gelişim Süresince Anadolu ve Bağdat Demiryollart [The Anatolia and Baghdad Railways in the development process of German - Turkish relationship] (Istanbul: Arba 
constructing the railways, Anatolian Railways have primarily constructed the Izmit - Adapazari line. The construction of the Izmit - Ankara line had made a fast progress, and the first train of the Anatolian Railway Company had arrived to Ankara on November $27^{\text {th }}, 1892 .{ }^{15}$ On the railways that have arrived to Ankara, Abdülhamit II wanted to extend it to the other cities of Anatolia, thus he conferred to Germany on this matter. Making a fast progress in Anatolia in the leadership of the Deutsche Bank, the Anatolian Railway Company's request of obtaining the privilege of Eskisehir - the Konya railway line brought the intense prevention efforts of the French and the English alongside with it. The main reason of these prevention efforts was the progress made by the German capital advancing by the help of the Deutsche Bank on the way to become the biggest power in the Ottoman Empire by increasing its achieved activity. The English had reasonable grounds on their side in refusing the extension of the railways until Konya. Primarily, Konya and its vicinity were the hinterland of the Izmir - Aydin railway line. The same situation also applied to the Izmir - Kasaba Railways controlled by the French. Both of the railway companies were thinking that Konya and its vicinity would no longer be their zone of influence if the Konya railway line was constructed by the Deutsche Bank. ${ }^{16}$ Despite all the prevention and the competition of the international capital, the construction and operating privilege of the Eskisehir Konya Railway was given to the Anatolian Railway Company on February $15^{\text {th }}, 1893 .{ }^{17}$ For the Konya Railways, the tithe of Trabzon and Gümüşhane districts had been shown as the kilometer insurance, and the collection work of the said tax was left to the Public Debts. ${ }^{18}$ It is understood that the railway company had primarily requested 14,000 francs collateral for the Konya line. However, after the last conference made between the Trade and Agriculture Minister Mahmut Celaleddin Pasha and Dr. Kurt Zander on March $15^{\text {th }}, 1893$, the railway company was dispensed with the portion which exceeds 5,000 francs of the kilometer insurance by considering the situation the Ottoman

Publications, 1988), 67; Y. N. Karkar, Railway Development in the Ottoman Empire 1856 1914 (New York: Vantage Press, 1972), $71-72$.

15. Ozyuksel, 1988, 76; Karkar, 1972, 72; Ortayli, 2006, 120 states that the railway line reached Ankara in January, 1893.

16. O. Kurmus, Emperyalizmin Türkiye'ye Girişi [The Entry of Imperialism to Turkey] (Istanbul: Bilim Publications, 1974), 51 - 75; B. S. Baykal, Das Bagdad - Bahn - Problem 1890 - 1903. Freiburg im Breisgau: Druck von Rudolf Goldschagg, 1935, 30 - 31; L. Rathmann, Berlin - Bağdat Alman Emperyalizminin Türkiye'ye Girişi [The Entrance of BerlinBaghdad German Imperialism to Turkey], trans. Ragıp Zarakolu (Istanbul: Belge Publications, 1982), 46 - 47; Ozyuksel, 1988, 80.

17. E. M. Earle, Turkey, the Great Powers and the Bagdad Railway (New York: The Macmillan Company, 1924), 33; Karkar, 1972, 72; Ozyuksel, 1988, 83; Ortayl1, 2006, 120; Issawi, 1980, 188 states the previlege granting date as 13th of February 1983, whereas M. Albayrak, "Osmanlı - Alman İlişkilerinin Gelişimi ve Bağdat Demiryolu'nun Yapımı" [The Development of Ottoman-German Relationships and the Construction of the Baghdad Railway], OTAM, no 6 (1995): 16 states it as the 16th of February, 1892.

18. Issawi, 1980, 189; Ozyuksel, 1988, 84 - 85; Karkar, 1972, 72. 
treasury was in. It is also understood that this insurance was then commuted in the name of the Anatolian Railway Company in the following years. ${ }^{19}$

We consider the Anatolian Railway Company's acceptance of 5,000 francs amount as the kilometer insurance for the Eskisehir - Konya Railway line as meaningful. ${ }^{20}$ It is also understood that the Ankara - Kayseri line which is in the same concession agreement did not seem as a reasonable line by the company. Because the Germans wanted more to construct lines which had lower construction costs. At the same time, the interest and depreciation amounts of the bonds of the lines to be constructed were also expected to be compensated in a couple of years. We understand that Alfred Kaulla was also not leaning towards the Ankara - Kayseri line by him requesting high amounts from the government as the kilometer insurance for the construction work of this line. ${ }^{21}$ Once the collateral requested for the kilometer insurance and the construction - operating privilege was received, it was time for the railway company to construct the railway line. The company that will construct the Konya Railway line was able to be established one year after the privilege was given. The company was named as Eskisehir - Konya Railway Construction Company, and it was established on March 1894. German capital and technique have played a significant role in the construction of the Konya Railway line. In this context, the Philipp Holzmann Company, domiciled in Frankfurt, undertook the construction work of the Konya line. The Philipp Holzmann Company had left the railway construction work to Ernst Mackensen. Mackensen was on duty since 1894, the foundation date of the construction company, up until the completion of the Konya - Bulgurlu line. ${ }^{22}$ The Anatolian Railway Company had made a progress of approximately 445 $\mathrm{km}$ while constructing the Eskisehir - Konya Railway line. The construction speed of the Konya Railway line was worthy of consideration just like in the Izmit - Ankara line. ${ }^{23}$ The railway construction had overcome some problems rapidly, and the construction of the railway had continued towards the Konya city center after taking the Aksehir - Ilgin railway line into operation. The

19. A. Efe, "Almanya’ya Verilen İkinci Demiryolu İmtiyazı: Hububat Hattı" ["The Second Railway Privilege Granted to Germany: The Cereal Line"], OTAM, no18 (2005): 103; Issawi, 1980, 188 - 189; Karkar, 1972, 72; Ozyuksel, 1988, 87.

20. A. Gavriyel, Anadolu Osmanlı Demiryolu ve Bağdat Demiryolu Şirket-i Osmaniyesi İdaresinin İcyüzü [İnside Story of the Management of Anatolia Ottoman Railways and Baghdad Railways Company] (Dersaadet: Mahmut Bey Printing House, Year, 1327) Islamic Calendar, 15 states that through the Eskişehir - Konya Railway Line of Anatolia Railway Company, 6,156 francs in 1906, 6,981 francs in 1907, 5816 Francs in 1908 and 4,673 Francs in 1909 , were obtained as gross revenue. The average gross revenue for these fours years is 5,906 francs.

21. BOA. Y.A.RES [Prime Ministry Ottoman Archives, Y1ld1z Document] 29.C.1310, $62 / 53$.

22. F. Colak, Almanların Konya ve Çevresindeki Faaliyetleri - 19.Yüzyıl Sonu 20. Yüzyıl Başı [German Activities in Konya and its Vicinity at the end of $19^{\text {th }}$ century and the Beginning of $20^{\text {th }}$ century ] (Konya: Çizgi Bookstore, 2014), 119.

23. Gavriyel, 1327 Islamic Calendar, 13 states the length of Eskişehir - Konya line as 445 kilometers, 443 meters and 25 centimeters, whereas Salname-i Devlet-i Aliyye-i Osmaniye 1325 (Hijri 1322). Dersaadet: Ahmed İhsan Printing House, 507 states the total length of the railway as $433 \mathrm{~km} .685 \mathrm{mt}$. and $40 \mathrm{~cm}$. 
railway line had reached the Konya station on July $29^{\text {th }}, 1896$. By the arrival of railways to Konya, significant changes have started to be experienced. Konya Railways had caused a trade movement to start from Istanbul to the inner sections of Anatolia and to the southern regions, and significant changes have occurred in economic, social, cultural and communal sense as a result of this trade movement. While the railways were changing the architectural structures and the urban patterns of the cities, economically significant ventures such as the irrigation project was also attempted. Now we will see the change and the effects of the railway line on Konya. ${ }^{24}$

\section{Konya Railways and its Effects on Konya}

\section{The Effect of Railways on Agriculture Development}

The tithe revenues of Konya had a tendency to rise before the railways. By the arrival of railways to Konya, the tithe revenues have reached higher amounts. The revenues of Aksehir, Ilgin and Konya districts located on the Konya railway route before the construction of railways in 1312 Hijri (1894-5) and their revenues after the railway arrived to Konya in 1318 Hijri (1900-1) may provide us information about the quality and quantity of agricultural production: ${ }^{25}$

Table 1. The Revenues of Aksehir, Ilgin and Konya Districts Located on Konya Railway Route

\begin{tabular}{|l|c|c|c|c|}
\hline Years & Cattle Tax & Tithe & Other Incomes & Total \\
\hline $1894 / 5$ & 3.486 .044 & 2.147 .317 & 3.027 .808 & 8.661 .169 \\
\hline $1900 / 1$ & 4.982 .563 & 4.969 .950 & 2.813 .801 & 12.766 .314 \\
\hline Increase \% & $42.9 \%$ & $131.5 \%$ & $-7 \%$ & $47.8 \%$ \\
\hline
\end{tabular}

Source: "Bir devlet adamının" Mehmet Tevfik Bey'in (Biren) 1993: 222.

In order to show the contribution of the railways to agricultural production, and to make a comparison, an obvious difference is observed when the revenues of Beysehir, Seydisehir, Bozkir, Karaman, Eregli, Karapinar and Kochisar districts, which are not located on Konya route, in 1312 Hijri (18945) and the revenues in 1318 Hijri (1900-1) were compared to the districts located on the railway route. ${ }^{26}$ Various attempts on the increase in the revenues have played a significant role in order to improve the opportunities in local

24. Efe, 2005, 108; Y1lmaz, 2015, 89 - 92; Earle, 1924, 33; Ozyuksel, 1988, 88.

25. F. Rezan Hürmen, "Bir devlet adamının" Mehmet Tevfik Bey'in (Biren) II. Abdülhamid, Meşrutiyet ve Mütareke devri Hatıraları 1 [II. Abdulhamit, Constitutional and the Armistice Era Memories of Mehmet Tevfik Bey a Statesman] (Istanbul: Arma Publications, 1993), 222.

26. Ibid., 1993, 222. 
transportation, to deliver the agricultural products to railway stations through the railways agencies, to establish companies for the railway company to increase agricultural production, to carry out the sales of agricultural machines and tools, and also to break the prejudice of farmers. ${ }^{27}$ It is needed to be cautious on explaining the increase in the revenues only by the railways. The dependency of agricultural production to climate conditions, the role and importance of Public Debts Administration in tax collection prevent the revenue increase to be explained with only one factor. It is also understood that railways have significantly affected the grain delivery. We see that the grain delivery of the Konya - Eskisehir line increased by two-folds in such a short time like ten years between the years the railway line arrived to Konya in 1896 - 1900 and 1901 - 1907. The amount of grain delivery made on the EskisehirKonya Railway line since its opening date 1896 until 1907 is presented in Table 2. ${ }^{28}$

Table 2. Grain Transportation on the Eskisehir--Konya Railway Line between 1896 - 1907 (in cwt)

\begin{tabular}{|l|c|}
\hline Years & Quantity \\
\hline 1896 & 1.002 .000 \\
\hline 1897 & 2.135 .460 \\
\hline 1898 & 907.420 \\
\hline 1899 & 215.740 \\
\hline 1900 & 1.097 .120 \\
\hline 1901 & 1.860 .200 \\
\hline 1902 & 2.443 .440 \\
\hline 1903 & 1.227 .280 \\
\hline 1904 & 1.984 .040 \\
\hline 1905 & 2.499 .690 \\
\hline 1906 & 1.499 .660 \\
\hline 1907 & 1.682 .600 \\
\hline
\end{tabular}

As can be understood from the numbers above, Konya started to become an important grain supplier for the community of Istanbul. The prime quality wheat and grain of Konya were sent to Istanbul to supply the community of Istanbul with food. ${ }^{29}$ The anatolia Railways decided to increase the utilization of agricultural machinery in order to draw advantages from the production potential developing along the rail line, as well as from grain transportation.

27. Yılmaz, 2015, 94 - 95; Özyüksel, 1988, 88 - 90; M. Baskıcı, "Osmanlı Tarımında Makineleşme: 1870 - 1914" ["Mechanization in the Ottoman Agriculture"], Ankara University Faculty of Political Sciences Magazine, no. 1, 30 - 52.

28. D. Quataert, Anadolu'da Osmanll Reformu ve Tarlm 1876-1908 [Ottoman Reform in Anatolia and Agriculture 1876 - 1908], trans. Nilay Özok Gündoğan Azat Zana Gündoğan, (Istanbul: Türkiye İş Bankası Kültür Publications, 2008), 321compiled from appendix 2, fig. H.

29. Le Journal de la Chambre de Commerce de Constantinople [Journal of the Chamber of Commerce of Constantinople] (March 28th 1903) no 951 explains that prime and second quality wheat was sent to Istanbul from Konya and the sales figures for each of the types of wheat are given in dollar currency. 
We can see that the company was sending treshing machines to Konya, for this purpose. $^{30}$

\section{Effects of the Railways on Social Developments and Changes}

It can be said that, with the construction of the railways, a set of social and cultural changes occurred in Konya. The first signs regarding this change were witnessed around the Konya Terminal. The majority of the laborers who were participating in the tasks that required skilled laborers during the construction of the railway line were formed by the citizens of Europe and especially the Italian. During the construction of the Eskisehir - Konya railway line, the Italian workers were involving in the fields such as stone and brick works. ${ }^{31}$ Following the completion of the Konya Railway construction, some of the foreign workers even settled in the area around the Konya Terminal. However, it can be seen that the consumption patterns of the workers who settled around the Konya Terminal were different from the consumption pattern of the locals. This was why the products these foreign workers needed, like margarine and lard, were being sent from Istanbul to Konya. ${ }^{32}$ The employment policies of the Anatolia Railway Company, started to increase the current tension in the Ottoman community, from the late $19^{\text {th }}$ century on. ${ }^{33}$ The emergence of conflicts between the railway workers and the natives revives the problem of cultural adaptation and proves that differentness is not a concept that is easy to adopt. $^{34}$

Sites and facilities which were unusual for the city also started to appear in Konya following the completion of the railways. It can be seen that 7 restaurants, 35 bars/alehouses and 6 hotels opened in Konya within the following three years after the railways reached Konya, in 1899. The establishment of the hotels in Konya, besides enabling the cultural expansion, has also brought social mobility along. The number of passengers who travelled to Konya via the railway increased and undoubtedly new consumption patterns were also embraced. ${ }^{35}$ The Grand de Baghdad, Selçuk Palas, Hotel Osmaniye and Hotel Vatan were among the hotels grouping together around the Konya Terminal. ${ }^{36}$ The number of the hotels showed further increase during the following periods. Such that, what we learn from

30. BOA. BEO [Prime Ministry Ottoman Archives, High Porte Document Room].16. RA. $1325,3043 / 228179$.

31. D. Quataert, Osmanlı Devleti'nde Avrupa İktisadi Yayılımı ve Direniş (1881 - 1908) [Reactions to European Economic Penetration in the Ottoman Empire 1881 - 1908] (Ankara: Yurt Publications, 1987), 70.

32. Commerciale du Levant Bulletin Mensuel de la Chambre de Commerce Française de Constantinople [Commerciale du Levant Monthly Bulletin of Constantinople's French Chamber of Commerce] (31st of July, 1906). Lettre De Koniah [Koniah's letter], 165 - 168.

33. Quataert, 1985, $1634-1635$.

34.Quataert, 1987, 70.

35. Konya Province Yearbook, 1317 Islamic Calendar, no. 28, 61.

36. A. S. Odabaş1, 20.Yüzyıl Başlarında Konya'nın Görünümü[Physical Appearance of Konya at the begining of 20th Century] (Konya: Konya Governorate, Provincial Directorate of Culture Publications, 1998), $38-42$. 
the Konya Province Yearbook dated 1906/7 (Julian Calendar 1322) is that 44 hotels and coffeehouses in total, were established in Konya by that date. ${ }^{37}$ The architectural influences of the railways on Konya can be observed in the terminal house and the lodging buildings in the Konya Terminal, featuring the characteristics of German architecture. We can say that, as the Konya Terminal was located in the west of the city, the commercial places and markets were tending to shift towards the west of the city. Modern houses and new stores also began to be built along Mimar Muzaffer Avenue and Istasyon Avenue, during the same period. The railways, bringing along new lifestyles, also led to the development of a new architectural style that was not seen in Konya until that day. ${ }^{38}$ The relative remoteness of the station to the city centre of Konya, resulted in the revival of the occupation of a horse-drawn carriage. It was seen in time that due to the distance between the city centre and the station, the horse-drawn vehicles were falling short of satisfying the needs of transportation and therefore the horsecars, that were no longer used in Thessaloniki since they had started to use electric tramways, were transported to Konya by the former governor of Konya, Ferid Pasha of Vlorë, for being operated by a private company, in 1906 . The horsecars were being run on the route between Türbe Önü -Mevlana Mausoleum- and the station. The horsecars departing from the front of Amil Çelebi's house located at Türbe Önü, advanced to Istanbul Avenue through the Eski Türbe Avenue and then passed through the site that is known as Fatih Bazaar today and arrived at Kayalı Park. Heading towards Araboğlu Makası afterwards, the horsecar passed through the street in front of the Catholic Church and the Hospital of Doctor Dat to arrive at Arapoğlu Kosti and then advanced towards the station as the last stop. ${ }^{39}$

\section{Effects of the Railways on Cultural Developments and Changes}

There were no modern entertainment venues and places when the railway line reached Konya in July, 1896. However, we can witness the opening of 35 bars and alehouses within the following three years -until 1899- after the railway reached Konya. The establishment of 7 restaurants (cook shops) also shows that the locals of Konya began to spend more time outside their homes and began to adopt certain consumption patterns. Moreover, it can be said that with the changes in daily life, the social relations between the people who came together in certain places began to change. ${ }^{40}$ That being said, with the completion of the railways, access to periodicals was rendered possible and the popularity of them across the city has increased. Before the railways, only the Konya Provincial Newspaper (1869), was published in Konya. It was published

37. In Konya Province Yearbook, 1322 Julian Calendar, 67, the number of hotels and coffeehouses is stated as 44 . However, the number of the hotels among these is not being mentioned.

38. Atalay, 2010, 13; Quataert, 1985, 1634; Y1lmaz, 2015, 105.

39. Odabasi, 1998, 147 - 148; Y1lmaz, 2015, 45 - 46.

40. Konya Province Yearbook, 1317 Islamic Calendar, no. 28, 61. 
in Turkish and the content was consisting of the official announcements, news from the capital of the empire, Istanbul and articles on agriculture. Before the railways, the number of newspapers delivered to the city was 2,000 times less than that of the population. However, with the completion of the railways, newspapers and magazines in English, Russian and particularly in French began to be read and have gained popularity. Periodicals such as Le Matin, I'illustration, Le Temps, Le Jornal, La Lecture Pour Tous, Le Rire, Les Anneles Poliqitues et Litteraries, Le Journal de St. Petersburg, Le Novoye' Vremia, Le Tageblatt, Le Times can be named as a few of the newspapers that started to be delivered to the city. ${ }^{41}$ Another effect of the railways was the arrival of German tradesmen and the role they played in business in Konya. One of them, the manager of a German company, rented the first 26 stores and coffeehouses from the entrance of Türbe Bazaar, in Konya. Emil Karayif, the company manager, also paid the charter prices in advance. It can be said based upon this example that the German were banding together in certain locations of the city centre of Konya and began to maintain their social lives in these locations. ${ }^{42}$ In addition, it was stated by the western pilgrims who have visited Konya in the following years that, with the railways, it became possible to find the American and European production food in Konya markets and bazaars and that these products were consumed by the locals of Konya as well. ${ }^{43}$

\section{Konya Railways and Konya Plain Irrigation Project}

Conducted by means of Anatolia Railways that reached Konya in July, 1896, the Konya Plain Irrigation Project aiming to irrigate the Konya Plain as well as to enhance agricultural production and extend the cultivable land, is known as one of the most important irrigation projects worldwide in the $20^{\text {th }}$ century, besides being the first modern irrigation project to have been carried out in Turkey, in the first quarter of the $20^{\text {th }}$ century. The idea of the irrigation of the Konya Plain actually dates back to the late $18^{\text {th }}$ century and the first quarter of the $19^{\text {th }}$ century. ${ }^{44}$ Examining the physical and topographic

41. Commerciale du Levant Bulletin Mensuel de la Chambre de Commerce Française de Constantinople (31st of July, 1905). Lettre de Koniah, 308 - 312.

42. Colak, 2014, 235

43. B. Horvath, Anadolu 1913 [Anatolia 1913], trans. Tarık Demirkan (Istanbul: Tarih Vakfi Yurt Publications, 1997), $16-17$.

44. O. F. Y1lmaz, Osmanlı'nın Konya Ovası Sulama Projesi [Ottoman Project of Konya Plain Irrigation] (Istanbul: Camlica Publications, 2010), 5 states that the works were initiated in 1819 by Karaman Governor Celik Mehmet Pasa whereas, A. Altuntas, "Konya - Çumra Ovası'nın Sulanmasının Tarihçesi ve Kuru Kafa Mehmed Efendi" ["History of Konya - Çumra Plain Irrigation and Kuru Kafa Mehmet Efendi"] I. Uluslar Arası Çatalhöyük'ten Günümüze Çumra Kongresi Bildirileri (Konya: Çumra Municipality Publications, 2001), 151 gives 1796 as the date the efforts were initiated. M. Bildirici, Tarihi Su Yapıları Konya, Karaman, Niğde, Aksaray, Yalvaç, Side, Mut, Silifke [Historical Water Structures: Konya, Karaman, Niğde, Aksaray, Yalvaç, Side, Mut, Silifke] (Ankara: DSİ Publications, 1994), 89 states that the first effort aiming the irrigation of Konya Plain was in 1819. M. S. Dogan, "Konya'nın Su İle İlgili Efsaneleri" ["Legends About Water in Konya"] in İpek Yolu Özel Sayı Konya Kitabı V. ed. Y. 
conditions of the Beyşehir Lake and the Konya Water Basin between the dates of July 12 - 19, 1903 and submitting a 12 page report on the results of the surveys he conducted, to the respective authorities, on August the $3^{\text {rd }}, 1903$, A. Waldrop, who worked in Anatolia Railway Company, has made great contributions in the realization of the irrigation project. Waldrop also prepared another report in 1904. This report was prepared in consequence of the approval of the report with the date 1903. ${ }^{45}$ The bidding process was commenced in 1906 in pursuit of the surveys that were necessary for the actualization of the Konya Plain Irrigation Project, and was completed in 1907. The project was given to the Anatolia Railway Company and the agreement was signed on the $20^{\text {th }}$ of November, 1907 -14.L. 1325 in the Islamic Calendar. The agreement, which was approved by Abdulhamid II with the promise that the project was going to be given to a company which has rendered significant services to the country and the government, was confirmed by the Sultan on the date of April the $30^{\text {th }}, 1908$. As can be exemplified with the above, the Anatolia Railway Company, not only contented itself with constructing railways in the lands of Anatolia, but also helped the economic development of the Ottoman, as well as putting a signature under significant projects in Anatolia, that supplied Germany with their agricultural needs. ${ }^{46}$ The company, together with German Philip Holzmann Company, established the construction company named Gesellschaft für die Bewasserung der Konia Ebene -Konya Plain Irrigation Company- and started the construction on the $1^{\text {st }}$ of July, 1908. They rapidly set up the railway line, with the same pace they carried out the Konya Plain Irrigation Project. ${ }^{47}$ Within the scope of the project which approximately took six years, eleven progress billing reports were issued. The last of these reports was bearing the date, $31^{\text {st }}$ of December, 1913 and so, the construction phase of the irrigation project that cost 19,500,000 Francs, was ultimately concluded. ${ }^{48}$ Having been unable to gain the favor from the irrigation project in the way expected due to the commencement of World War I in 1914, the government gave the Anatolia Railways the permit to run the irrigation facility for 5 years, in September, 1913. The company handed the facility over to the government after running it until May $1918 .^{49}$

Küçükdağ, 2002, 94 - 95, however, mentions the year 1879 for the first initiative regarding the irrigation of Konya Plain.

45. M. Bildirici, "Konya Ovası Sulaması" ["Konya Plain Irrigation"], I Uluslar Arast Çatalhöyük'ten Günümüze Çumra Kongresi Bildirileri. Konya: Cumra Municipality Publications, 2001, 161 - 168; Bildirici, 1994, 90 - 91; Colak, 2014, 155 - 157.

46. BOA. BEO [Prime Ministry Ottoman Archives, High Porte Document Room]. 14.L. 1325, 3188/239035; Kızılkaya and Akay, 2014, 44 - 46; Rathmann, 1982, 185- 186; Bildirici, 1994, 93.

47. R. I. Money, "The Irrigation of the Konia Plain", The Geographical Journal 54, no 5, (November, 1919): 298 - 303.

48. Kızlkaya and Akay, 2014, 78 - 79; Bildirici, 1994, $101-110$.

49. BOA. BEO [Prime Ministry Ottoman Archives, High Porte Document Room]. 14.L. 1325, 3188/239035; Kızılkaya and Akay, 2014, 44 - 46; Rathmann, 1982, 185 - 186; Bildirici, 1994, 115 - 117. 


\section{Conclusion}

The railways played significant roles in the transformation of numerous cities in the world, in terms of both modernization and architectural development. The railway that reached Konya in July, 1896 also, has brought many changes along. With the railways, in addition to the changes in the physical environment of the city, it became possible to see places and facilities that did not exist in the city before. Places of both accommodation and entertainment were forming a part of these new buildings. This situation proves that railways bring along significant social, economic and cultural institutions with them. Horsecar also, which is one of the symbols of the $20^{\text {th }}$ century Konya, started to appear in Konya, with the railways. The increase in loads and passenger transportation was also another reason that accelerated the emergence of new occupations. As the railways reached Konya, the grain need of Istanbul began to be fulfilled and Konya became a significant centre that supplied Istanbul in terms of food with the grain of Anatolia. Furthermore, significant changes from the cultural and social perspectives were also actualized by means of this new transportation system.

\section{Bibliography}

Albayrak, M. "Osmanlı - Alman İlişkilerinin Gelişimi ve Bağdat Demiryolu'nun Yapımı" [The Development of Ottoman-German Relationships and the Construction of the Baghdad Railway]. OTAM, no 6 (1995).

Altuntaş, A. "Konya - Çumra Ovası'nın Sulanmasının Tarihçesi ve Kuru Kafa Mehmed Efendi" ["History of Konya - Çumra Plain Irrigation and Kuru Kafa Mehmet Efendi"]. I. Uluslar Arası Çatalhöyük'ten Günümüze Çumra Kongresi Bildirileri. Konya: Çumra Municipality Publications, 2001.

Atalay, A. "Meşrutiyet'ten Cumhuriyet'e Konya'da Şirketleşme ve Milli Bankacılık Faaliyetleri" ["Incorporation and National Banking Activities from The Constitutional Period to The Republic Period"]. PhD diss., Selçuk University, 2010.

Baykal, B. S. Das Bagdad - Bahn - Problem 1890 - 1903. Freiburg im Breisgau: Druck von Rudolf Goldschagg, 1935.

Bildirici, M. Tarihi Su Yapıları Konya, Karaman, Niğde, Aksaray, Yalvaç, Side, Mut, Silifke [Historical Water Structures: Konya, Karaman, Niğde, Aksaray, Yalvaç, Side, Mut, Silifke]. Ankara: DSİ Publications, 1994.

Bildirici M. "Konya Ovası Sulaması" ["Konya Plain Irrigation"]. I. Uluslar Arası Çatalhöyük'ten Günümüze Çumra Kongresi Bildirileri. Konya: Çumra Municipality Publications, 2001.

Rezan Hürmen, H. "Bir devlet adamının" Mehmet Tevfik Bey'in (Biren) II. Abdülhamid, Meşrutiyet ve Mütareke devri Hatıraları 1 [II. Abdulhamit, Constitutional and the Armistice Era Memories of Mehmet Tevfik Bey a Statesman]. Istanbul: Arma Publications, 1993.

BOA. Y.A.RES, [Turkish Prime Ministry Ottoman Archives, Yıldız Document]. 29.C.1310, 62/53.

BOA. BEO [Turkish Prime Ministry Ottoman Archives, High Porte Document Room]. 16. RA. $1325,3043 / 228179$. 
BOA. BEO [Turkish Prime Ministry Ottoman Archives, High Porte Document Room]. 16. B. $1325.3131 / 234768$.

$B O A$. BEO, [Turkish Prime Ministry Ottoman Archives, High Porte Document Room]. 14.L. 1325, 3188/239035.

Büyüksarıkulak, T. "II. Abdülhamit Dönemi Salnamelerine Göre Konya Vilayeti Merkez Sancağının İktisadi Durumu". Master's thesis, Selçuk University, 1988.

Çolak, F. Almanların Konya ve Çevresindeki Faaliyetleri - 19.Yüzyıl Sonu - 20. Yüzyll Başı [German Activities in Konya and its Vicinity at the end of 19th Century and the Beginning of 20th century ]. Konya: Çizgi Bookstore, 2014.

Commerciale Du Levant Bulletin Mensuel De La Chambre De Commerce Française $\mathrm{De}$ Constantinople [Commerciale Du Levant Monthly Bulletin of Constantinople's French Chamber of Commerce] (31st of July, 1905). Lettre De Koniah [Koniah's letter].

Commerciale Du Levant Bulletin Mensuel De La Chambre De Commerce Française De Constantinople (31st of July, 1906). Lettre De Koniah.

Cuinet, V. La Turquie d'Asie; géographie administrative, statistique descriptive et raisonnée de $l$ asie mineure [Asiatic Turkey; administrative geography, descriptive and reasoned statistics of Asia Minor]. Paris: E. Leroux, 1892.

Dogan, M. S. "Konya'nın Su İle İlgili Efsaneleri" ["Konya Water Related Myths"]. Ippek Yolu Özel Sayı Konya Kitabı V, edited by. Y. Küçükdağ, (2002).

Earle, E. M. Turkey, the Great Powers and the Bagdad Railway. New York: The Macmillan Company, 1924.

Efe, A. "Almanya'ya Verilen İkinci Demiryolu İmtiyazı: Hububat Hattı" ["The Second Railway Privilege Granted to Germany: The Cereal Line"]. OTAM, no18 (2005).

Efe, A. "Rayların Altında Kalan Mâkus Tarih: Değişen Eskişehir" ["The unfortunate history Stucked Under the Railraod Tracks: Changing Eskişehir"]. In Railways in the Republic Period Symposium, edited by Mukaddes Arslan, 117 - 118. Ankara: Atatürk Research Center, 2010.

Gavriyel, A. Anadolu Osmanlı Demiryolu ve Bağdat Demiryolu Şirket-i Osmaniyesi Ídaresinin İcyüzü [Inside Story of the Management of Anatolia Ottoman Railways and Baghdad Railways Company]. Dersaadet: Mahmut Bey Printing House, Islamic Calendar, 1327.

Horvath, B. Anadolu 1913 [Anatolia 1913]. Translated by Tarık Demirkan. Istanbul: Tarih Vakfi Yurt Publications, 1997.

Issawi, C. The Economic History of Turkey 1800 - 1914. Chicago: The University of Chicago Press, 1980.

Karkar, Y. N. Railway Development in the Ottoman Empire 1856 - 1914. New York: Vantage Press, 1972.

Kızılkaya, O., and T. Akay. II. Abdülhamit'in Tarımsal Kalkınma Hamlesi, Konya Ovasi Sulama Projesi [Agricultural Development Act of Abdulhamit II, Konya Plain Irrigation Project]. Ankara: Sonçağ Publications, 2014.

Konya Province Yearbook, 1294 Islamic Calendar, No. 10.

Konya Province Yearbook, Year, 1298 Islamic Calendar, No.14.

Konya Province Yearbook, 1310 Islamic Calendar, No.25.

Konya Province Yearbook, Year, 1317 Islamic Calendar, No. 28.

Konya Province Yearbook, Year, 1322 Julian Calendar.

Kurmus, O. Emperyalizmin Türkiye'ye Girişi [The Entry of Imperialism to Turkey]. İstanbul: Bilim Publications, 1974.

Le Journal de la Chambre de Commerce de Constantinople [Journal of the Chamber of Commerce of Constantinople] (28th of March 1903). no: 951. 
Money, R. I. "The Irrigation of the Konia Plain". The Geographical Journal 54, no 5, (November 1919).

Odabaşı, A. S. 20. Yüzyıl Başlarında Konya'nın Görünümü [Physical Appearance of Konya at the begining of 20th Century]. Konya: Konya Valiliği İl Kültür Müdürlüğü Publications, 1998.

Ortayli, I. Osmanlı Imparatorluğu'nda Alman Nüfuzu [German Influence in the Ottoman Empire]. Istanbul: Alkım Publications, 2006.

Önder, M. Mevlana Şehri Konya [City of the Mevlana, Konya]. Ankara: Konya Turizm Derneği Publications, 1971.

Ozyuksel, M. Osmanlı - Alman İlişkilerinin Gelişim Sürecinde Anadolu ve Bağdat Demiryollarl [The Anatolia and Baghdad Railways in the development process of German - Turkish relationship]. Istanbul: Arba Publications, 1988.

Quataert, D. "19. Yüzyılda Osmanlı İmparatorluğu'nda Demiryolları" ["Railways in the 19th century in Ottoman Empire"]. Tanzimat'tan Cumhuriyet'e Türkiye Ansiklopedisi. [From Tanzimat to Republican Era Turkey Encyclopedia] Vol.6. Istanbul: İletişim Publications, 1985.

Quataert, D. Osmanlı Devleti'nde Avrupa İktisadi Yayılımı ve Direniş (1881 - 1908) [Reactions to European Economic Penetration in the Ottoman Empire 1881 1908]. Ankara: Yurt Publications, 1987.

Quataert, D. Anadolu'da Osmanl Reformu ve Tartm 1876 - 1908 [Ottoman Reform in Anatolia and Agriculture 1876 - 1908]. Translated by Nilay Özok Gündoğan, Azat Zana Gündoğan. Istanbul: Türkiye İş Bankası Kültür Publications, 2008.

Rathmann, L. Berlin - Bağdat Alman Emperyalizminin Türkiye'ye Girişi [The Entrance of Berlin-Baghdad German Imperialism to Turkey]. Translated by Ragip Zarakolu. Istanbul: Belge Publications, 1982.

Salname-i Devlet-i Aliyye-i Osmaniye 1325 (Hijri 1322). Dersaadet: Ahmed İhsan Printing House

Velay, D. Türkiye Maliye Tarihi [Financial History of Turkey]. Ministry of Finance, Board of Review Publication, 1978.

Yılmaz, M. "Konya ve Havalisinde 1303 (1887) Kitlı̆̆ı ve Alınan Bazı Tedbirler" ["Famine in Konya and its Vicinity in 1303 Hijri (1887) and the Some Measures Taken to Prevent It"] in Yeni İpek Yolu Mazagine Konya I Book Special Edition, edited by Yusuf Küçükdağ, 135 - 146. 1998.

Yılmaz, O. F. Osmanlı'nın Konya Ovası Sulama Projesi [Ottoman Project of Konya Plain Irrigation]. Istanbul: Camlica Publicaitons, 2010.

Yılmaz, E. "II. Abdülhamit Döneminde Konya ve Kentin Yapısal Değişimi". Master's thesis, Anadolu University Institute of Social Sciences, 2015. 
